\title{
On the monetary measures of global liquidity
}

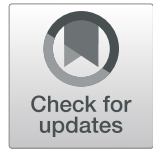

\author{
Israr Ahmad Shah Hashmi and Arshad Ali Bhatti ${ }^{*}$ (D)
}

\author{
* Correspondence: arshad_bhatti@ \\ iiu.edu.pk \\ School of Economics, IIIE, \\ International Islamic University, \\ Islamabad, Pakistan
}

\begin{abstract}
This study constructs and examines the dynamics of theoretical and atheoretical measures of global liquidity, using monthly data on the components of broad money over the period 2001 M12-2017 M12 for 39 high income countries. We group the countries into five regional blocks as categorized by the World Bank: East Asia and the Pacific, Europe and Central Asia, Latin America and the Caribbean, Middle East and North Africa, and North America. The atheoretical measures exploited by this study comprise of the simple-sum, GDP-weighted growth rates and PCA based aggregation methods; whereas theoretical measures include the currency equivalent and Divisia index techniques of monetary aggregation. We employ a graphical approach to investigate the trends and dynamics of the aggregates overtime, and a cross-correlation between cyclical components of global real economic activity and the lag of cyclical components of the measures of global liquidity to gauge the strength of their associations. The findings of this study reveal that theoretical measures outperform atheoretical ones in effective delineation of financial and liquidity conditions, and policy stance. Their cyclical components are also strongly associated with those of global real business activity. The currency equivalent measure, besides being a leading indicator of the shift in policy stance, has a sturdy association with global real business activity. Moreover, the theoretical measures, as noted by some empirical studies, contain some information content that the atheoretical lack.
\end{abstract}

Keywords: Monetary aggregates, Divisia index, Currency equivalent, Simple-sum, GDP-weighted growth rates, PCA

JEL classification: E40, E51, E52

\section{Introduction}

In the aftermath of the global financial crisis (hereafter GFC), global liquidity has remained central to the debate on an international financial system. There prevails a perception that global liquidity is a powerful driver of cross-border capital flows, global inflation, asset prices, and financial stability (Cohen et al. 2017). The monetary aggregates view recognizes its role as one of the chief determinants of aggregate demand, goods price inflation and cross-border macroeconomic spillovers (Chen et al. 2012; Rüffer and Stracca 2006; Baks and Kramer 1999). Another stance, supported by empirical findings, is of the view that an abnormal increase in private credit coupled with a rise in asset prices may lead to financial distress (Borio and Drehmann 2009).

(C) The Author(s). 2019 Open Access This article is distributed under the terms of the Creative Commons Attribution 4.0 International License (http://creativecommons.org/licenses/by/4.0/), which permits unrestricted use, distribution, and reproduction in any medium, provided you give appropriate credit to the original author(s) and the source, provide a link to the Creative Commons license, and indicate if changes were made. 
Aggregate credit flows are also closely associated with financial vulnerability. This international component is of much significance in the assessment of global liquidity. Though international credit is very small relative to domestic credit, it is highly correlated with booms and busts in global financial conditions (Cohen et al., 2017; CGFS 2011).

Despite the tremendous importance of global liquidity lime lighted by many empirical studies, it still lacks agreed definition and measure (Domanski et al. 2011; Landau 2011). Generally, global liquidity is considered as an "ease of financing in global financial centres", though it is a challenging task. Therefore, global liquidity remains an elusive concept (Cohen et al. 2017; Domanski et al. 2011). The concept of global liquidity can best be explained by shedding light on its foundations. Liquidity, in general, refers to the degree of ease and speed with which an asset can be converted into another asset (purchasing power). Keeping in view this notion of 'liquidity' and in the context of current financial system, two concepts of global liquidity are most important: market liquidity and funding liquidity (CGFS 2011). Market liquidity refers to the situation where immediate or short notice sale of an asset has least impact on its price. A lesser impact on asset price is associated with more market liquidity. Similarly, funding liquidity involves raising cash by borrowing with least impact on borrowing cost. Less of an impact on borrowing cost indicates greater funding liquidity (Cohen et al. 2017).

A wide range of measures of different aspects of global liquidity are suggested in the literature. ${ }^{1}$ The selection of measures depends primarily on the aspect of global liquidity being focused on. Constructing the measure of global liquidity, one must be mindful of the fact that global liquidity is mainly determined by the interactions of financial institutions and private investors. Financial institutions fetch market liquidity to the securities market through their trading activities (buying securities) and funding liquidity to the borrowers through their lending activities. But the question arises: Which measure, or aspect of global liquidity is relatively better to explain financial and macroeconomic conditions? To answer this question, some researchers are of the view that various concepts of liquidity are closely related (Baks and Kramer 1999; Cohen et al. 2017). For instance, monetary liquidity can be an important source of funding in the securities market. Increased market liquidity lowers the funding cost (interest rate) and hence supports market making activities. The net supply of securities might tend to increase in periods of ample market liquidity because monetary markets are generally receptive to new issues. On the other hand, money demand, willingness of financial institutions and investors to take risk, willingness of corporations to take on debt, and global liquidity may increase simultaneously during periods of improved economic prospects. Clearly, relationships among different types of liquidity assign a key role to central banks and hence to monetary liquidity (Baks and Kramer 1999).

Monetary and credit measures are therefore the best options to proxy the quantity and volume of global liquidity. Moreover, other aspects of global liquidity are also primarily determined by money and credit supply in global financial centres. The ability of financial and non-financial institutions to advance credit is further determined by the availability of monetary services in the market. Thus, credit can also be proxied by monetary assets (Chung et al., 2014). Inspired by this stance, our study also constructs monetary measures of global liquidity.

This investigation constructs and examines the dynamics and correlation of the secular components of global real economic activity along with its lags of five different 
monetary measures of global liquidity: simple sum, GDP-weighted growth rates, currency equivalent (hereafter CE), Divisia index, and Principal Component Analysis (hereafter PCA) based measures. We firstly construct and investigate the dynamics of aggregates at a regional level and then at a global level. For this, sampled countries are grouped into five regional blocks, as categorized by the World Bank. The regional blocks are: (i) East Asia and the Pacific (ii) Europe and Central Asia (iii) Latin America and the Caribbean (iv) Middle East and North Africa, and (v) North America. On our end, we use monthly data for sampled high income countries, spanning the period December 2001 to December 2017.

The study is organized as follows: section 2 reviews the measures of global liquidity suggested and utilized by theorists and empirical researchers, section 3 describes the data and its sources, section 4 elaborates the aggregation procedures involved in different measures, section 5 examines and discusses the dynamics of aggregates and the connection between secular components, whereas section 6 contains the conclusion and policy recommendations.

\section{Review of literature}

This section reviews the measures of global liquidity suggested and used in existing literature. Describing overall measures suggested for different aspects of global liquidity, it discusses the measures utilized in empirical studies, taking a special look at the monetary measures of global liquid, which most of the empirical studies have utilized for their explorations.

In a broader sense, global liquidity measures can be classified into two categories. The first category includes quantity-based measures which generally employ domestic and cross-border bank credit, year-on-year growth rate of international bank claims, and credit to GDP ratios, as measures of the credit aspect of global liquidity (McGuire and Sushko 2015; Bruno and Shin 2014; Domanski et al. 2011; Landau 2011). The measures of monetary liquidity include base money and broader money aggregates, central bank assets, foreign exchange reserves, and official foreign exchange reserves as a percentage of the GDP. The indicators for funding liquidity include debt and bank lending (net international debt securities issuance), bond and equity flows, the banking sector's loan to deposit and non-core liabilities ratios, bank liquidity ratios, maturity mismatch measures and commercial paper (CP) market volumes (McGuire and Sushko 2015; Domanski et al. 2011; Landau 2011). Further, the proxies suggested for global excess and market liquidities are positive deviations of global credit to GDP ratios from their long-term trend over an extended period (credit-to-GDP gaps) and transaction volumes, respectively (Domanski et al. 2011; Landau 2011).

The second category is the price-based measures which include policy and money market interest rates, and monetary condition indices, as indicators of monetary liquidity. The funding liquidity can be proxied by major policy rates including interbank money, wholesale funding markets and long-term capital market rates. The business and mortgage loan rates represent the financial conditions faced by borrowers, whereas long-term government bond yields and money market rates depict the liquidity and funding conditions of banks. Further, volatility of the stock market is, sometimes, used as a proxy for investor risk appetite and willingness to provide funding. In addition to that, indicators for short-term and cross-currency funding conditions are credit default 
swap $^{2}$ (hereafter CDS) premia (five-year) in banks, Libor-OIS spread ${ }^{3}$ (three-month) and cross-currency basis swaps. Indicators for risk appetite and market positioning include VIX ${ }^{4}$ and MOVE $^{5}$ indices, net inflows into hedge funds, carry-to-risk ratios, and the non-commercial net position of the Commodity Futures Trading Commission (hereafter CFTC) (McGuire and Sushko 2015; Domanski et al. 2011; Landau, 2011).

The largest portion of empirical literature has utilized monetary measures of global liquidity. The oldest and most traditional monetary aggregates have been constructed by simple-sum aggregation. Several studies employ a simple sum of monetary aggregates of major economies, converted into a common currency, as an indicator of global liquidity. This procedure of construction involves a sum of monetary aggregates especially broad money $\left(\mathrm{M}_{2}, \mathrm{M}_{3}\right.$ or whichever is available for each economy) (Beckmann et al. 2014; Belke et al. 2013; Sousa and Zaghini 2007; Baks and Kramer, 1999). In addition, Sousa and Zaghini (2008) use a simple-sum of some monetary aggregates of reference countries, converted into common currency based on euro-based purchasing power parity (PPP). Yet, some other studies credit aggregates as a measure of global liquidity (Chung et al. 2014). Cerutti et al. (2017) use a volume of cross-border bank flows of the sampled countries.

A chunk of empirical literature also uses the sum of monetary assets across the world as an indicator of global liquidity. A group of this sort of studies exploits the sum of base money of the US and the world foreign exchange reserves (Belke et al. 2013; Darius 2010). Belke et al. (2013) take just the total foreign exchange reserves of the world excluding gold. Adding to that, Belke et al. (2014) utilizes the ratio of total nominal money of the world to the world's nominal GDP as a proxy of global liquidity. However, Brana et al. (2012) use it instead as a measure of global excess liquidity.

The procedure of simple sum aggregation basically involves addition of the dollar values (converted into a single currency) of all financial assets intended for inclusion in monetary aggregates. Hence, this technique assigns equal weights to all financial assets regardless of varying degrees of "moneyness". This is based on a strong assumption that all components of monetary aggregates are perfect substitutes (Barnett and Su 2017; Darvas 2015; Barnett 1980, 2003, Alkhareif and Barnett, 2012) and gains theoretical support from the notion of classical economists that the essential function of money is to serve as a medium of exchange - to facilitate transactions only. Thus, based on this definition of money, monetary aggregates comprise of only two components: currency and demand deposits (Barnett, 1984).

Another strand of literature utilizes the GDP-weighted sum of monetary aggregates as a measure of global liquidity. For instance, Baks and Kramer (1999) utilize the weighted sum of growth rates of monetary aggregates for $G_{7}$ countries. Some other studies, following Beyer et al. (2001), construct and utilize a monetary index of global liquidity by assigning weights to the growth rates of a country's monetary aggregate (like, M2, M3). The weights are assigned equal to the GDP share of the respective country in the group of sampled countries (Belke and Keil 2016; Belke et al. 2010; Giese and Tuxen 2007). Another study employs factor models to construct a measure of global liquidity based on common factors of quantity and price-based indicators which include monetary aggregates, domestic and cross-border credit aggregates, retail lending rates, government bond yields, money market rates and stock market volatility (Eickmeier et al. 2014). 
But the GDP-weighted measures, like summation measures, lack a theoretical foundation. They do not assign weights to monetary assets based on their moneyness but in accordance with the level of economic activity (GDP) of the concerned country. Hence, the indices constructed through procedures not supported by monetary theory fail to measure liquidity of assets accurately. These indices ignore the importance of liquidness of the components of monetary aggregates by allocating equal weights to all of them, while aggregation is carried out within a country. They, like simple sum methods, consider the components of monetary aggregates as perfect substitutes of one another. Further, any weighting scheme, without theory, is questionable (Serletis and Molik 2000).

In view of limitations of simple sum and GDP-weighted aggregation procedures, researchers have attempted to measure moneyness of assets to a somewhat better degree. In this direction, Barnett (1980) and Rotemberg et al. (1995) have made valuable contributions by introducing indices having theoretical foundations, Divisia and CE procedures of monetary aggregation. Both the procedures assign weights to monetary assets according to their characteristic of moneyness. However, Divisia and CE measures differ from each other to a considerable extent. The Divisia index functions as a flow measure while the $\mathrm{CE}$ index acts as a stock measure.

After the seminal work of Barnett (1980), researchers devoted their efforts to the construction and investigation of the properties of Divisia monetary aggregates. The Centre for Financial Stability (hereafter CFS) ${ }^{6}$ maintains a directory of the studies that construct Divisia monetary indices for different countries, though most of the studies cover only a single country (Schunk 2001; Drake et al. 2000; Thornton and Yue 1992; Barnett et al. 1984). Similarly, the investigation of studies using the CE technique also covers single country (Serletis and Molik 2000). However, some studies endeavour to construct Divisia monetary aggregation across the countries, despite having only been conducted on euro area (Barnett and Gaekwad 2018; Darvas 2015; Binner et al. 2009; Stracca 2004; Barnett 2003). Another study of this sort is conducted only on the member countries of the Gulf Cooperation Council (Alkhareif and Barnett 2012).

Moreover, most of the investigations reveal that the Divisia index outperforms other measures in forecasting real activities and inflation, based on some other criteria (Darvas 2015; Alkhareif and Barnett 2012; Schunk 2001; Barnett et al. 1984). Hjertstrand et al. (2018) further investigate superlative, non-superlative and atheoretical indexes to identify which measures better fit the data and contain the information and properties of weak separability as obtained from revealed preference tests. Relying on the results of various tests executed, they conclude that superlative indexes perform far better than others. Additionally, atheoretical measures present the poorest performance.

It is evident from the review of literature that most of the monetary measures of global liquidity lack theoretical foundations. Only one study, Baks and Kramer (1999), has used Divisia index for G7 countries. Motivated by the advocacy for the use of superlative indices for monetary aggregation and a great stress on the use of monetary indices backed by theory in the literature, this study constructs simple sum, GDP-weighted growth rates, Divisia, CE and PCA based measures of global liquidity. In this way this study contributes to the literature by constructing and comparing the dynamics of theoretical measures with those of atheoretical measures at regional and global levels. 


\section{Data descriptions and sources}

We use monthly data for high income ${ }^{7}$ countries spanning from December 2001 to December 2017. Our sample of countries includes Australia, Canada, Chile, the Czech Republic, Denmark, Euro area $\left(\mathrm{EU}_{19}\right),{ }^{8}$ Hong Kong, Hungary, Iceland, Israel, Japan, Korea Republic, New Zealand, Norway, Poland, Singapore, Sweden, Switzerland, the United Kingdom (UK), the United States (US) and Uruguay. The sample is primarily determined by the availability of data. ${ }^{9}$ Since countries do not follow a uniform definition of monetary aggregates, we use broad money as defined by the IMF as the broadest aggregate for each country. The data on broad money and its components is available for most of the sampled countries except Hong Kong, New Zealand, Singapore, the UK and the US. Further, the Monetary and Financial Statistics Compilation Guide prepared by the IMF identifies the counterparts of broad money for these countries. For example, M2 for the US, M3 for the euro area, M4 for the UK and M3 for other countries. We use broad money counterparts for these countries and derive their subcomponents by classifying the constituents of M1, M2 and M3 separately. For countries with the broadest aggregate of M3, we make three subcomponents: M1, ${ }^{10}$ the assets incorporated in M2 but not in M1 and the assets included in M3 but not in M2. In case of the US, we use currency in circulation, the assets included in M1 other than currency in circulation and the assets included in M2 but not in M1. Moreover, the broad money contains four components: currency in circulation, transferable deposits, other deposits included in broad money, and deposits other than securities included in broad money.

The data on monetary aggregates, interest rates, exchange rate and population has been extracted from International Financial Statistics (hereafter IFS) except for the US and the UK, where it has been taken from the Federal Reserve Economic Data (FRED), and Canada, where it has been taken from the Canadian central bank (CANSIM). The data on the OECD industrial production index has been taken from the OECD database. We use cubic spline interpolation for interest rates and linear interpolation for monetary aggregates where the period of missing data is less than one year. For longer periods (but less than three years) we use a regression technique; regressing the variable whose data is missing on related variables. For example, if the data on one component of broad money is short, we use the forecasted data by regressing that component on other components. Similarly, for interest rates, we regress the type of interest rate whose data is short on other types of interest rates. All the series of monetary aggregates are seasonally adjusted through the X11 process except where they are already available seasonally adjusted. ${ }^{11}$ We use linear interpolation to convert population data from annual frequency to monthly frequency.

\section{Measuring global liquidity}

This section discusses the techniques employed to measure global liquidity. We employ five different methods, namely Simple-Sum, GDP-weighted growth rates, PCA, CE and Divisia to measure global liquidity. Each method of aggregation is elaborated below.

\section{The simple-sum method}

This procedure involves the conversion of seasonally adjusted broad money of all countries into a common currency, which can be obtained by dividing the broad money by 
the respective country's exchange rate, and then summing the converted series up. It can be described as:

$$
\operatorname{SUM}_{k t}=\sum_{i=1}^{N} \frac{b m_{i t}}{e_{i t}} ; i \in k
$$

where, $S U M_{k t}$ is the regional aggregate of region $k$ in time $t, b m_{i t}$ is the broad money of country $i$ in time $t$ and $e_{i t}$ is the exchange rate of country $i$ in time $t$. Exchange rate implies the value of a US dollar in terms of domestic currency.

Furthermore, the range of $N$ varies from region to region. Its range for East Asia and the Pacific is six $(N=1,2, \ldots ., 6)$, ten for Europe and Central Asia $(N=1,2, \ldots ., 10)$, two for Latin America and the Caribbean $(N=1,2)$, one for the Middle East and North Africa $(N=1)$, two again for North America $(N=1,2)$, and 21 at a global level $(N=1,2$, ...., 21). Hereafter, its range will remain the same in all analyses.

\section{GDP-weighted growth rates method}

In this section, we follow Belke and Keil (2016), Giese and Tuxen (2007) and Beyer et al. (2001) to construct monetary aggregates at regional and global levels. This procedure of aggregation involves the conversion of nominal GDP of all countries into a common currency using purchasing power parity (PPP) exchange rates. Then each country's GDP share in the total group GDP is calculated. The GDP share of the country is used as a weight for that country. Hence country- specific weight of country $i$ in time $t$ is:

$$
w_{i t}=\frac{G D P_{i t} / e_{i t}^{P P P}}{\sum_{i=1}^{N}\left(G D P_{i t} / e_{i t}^{P P P}\right)}
$$

where, $w_{i t}$ is the weight, $G D P_{i t}$ is the nominal GDP and $e_{i t}^{P P P}$ is the purchasing power parity exchange rate of country $i$ in time $t$.

The growth rates of monetary aggregates constructed across the countries can be obtained by allotting the weights calculated above to the growth rate of broad money (in domestic currency) of the respective country.

$$
G_{t}=\sum_{i=1}^{N} w_{i t} g_{i t}
$$

where, $g_{i t}$ is the growth rate of broad money of country $i$ in time $t$ and $G_{t}$ is the aggregate growth rate in time $t$. Some studies use year specific weights at this stage of aggregation because the data on GDP is generally available in annual frequency (Belke and Keil 2016; Belke et al. 2014; Baks and Kramer 1999). We also use year specific weights at this step of aggregation.

The aggregate monetary index across the countries $M^{G D P}$ can be constructed by using an initial level 100 and multiplying it by aggregate weights computed above.

$$
M^{G D P}=\prod_{t=2}^{T}\left(1+G_{t}\right) \cdot 100
$$




\section{PCA-based aggregation}

The prime objective of PCA is to explain the variance of observed data by utilizing a few linear combinations of original data (Joint Research Centre-European Commission, 2008). The PCA-based aggregation procedure can be described as follows: Suppose we construct a monetary aggregate across the countries utilizing the data on broad money for $N$ countries. Here, we use broad money of each country converted into a common currency based on the respective country's exchange rate. A small number of variables (principal components) can capture a large proportion of the variation of the original $N$ variables. Further, the $P$ number of principal components can retain a high amount of the variability of the original variables even when $P<N$. However, the maximum number of principal components can be $N$.

$$
\begin{aligned}
& Z_{1}=a_{11} M_{1}+a_{22} M_{2}+\ldots+a_{1 N} M_{N} \\
& Z_{2}=a_{21} M_{1}+a_{22} M_{2}+\ldots+a_{2 N} M_{N} \\
& \cdot \\
& \cdot \\
& \cdot \\
& Z_{N}=a_{N 1} M_{1}+a_{N 2} M_{2}+\ldots+a_{N N} M_{N}
\end{aligned}
$$

where, $M_{i}$ is the broad money of country $i, Z_{i}$ is the $i^{\text {th }}$ principal component and $a_{i j}$ is a weight assigned to the broad money of country $j$ in principal component $i . a_{i j}$ is also termed as component or factor loading and is chosen in such a way that the principal components satisfy the following conditions.

a. The principal components are uncorrelated (orthogonal).

b. The first principal component explains the maximum proportion of the variance of variables. The second principal component explains the maximum of the remaining variance and so on. All the remaining variances are accounted for by the last component. Further,

$$
a_{i 1}^{2}+a_{i 2}^{2}+\ldots+a_{i N}^{2}=1 \text { and } i=1,2, \ldots, N \text {. }
$$

PCA involves tracing the eigenvalues which requires covariance matrix. So, the sample covariance matrix $C M$ can be expressed as:

$$
C M=\left[\begin{array}{ccc}
c m_{11} & \cdots & c m_{1 N} \\
\vdots & \ddots & \vdots \\
c m_{N 1} & \cdots & c m_{N N}
\end{array}\right]
$$

where, $\mathrm{cm}_{i i}$ is the variance of the monetary aggregate (broad money) of country $i$ and $c m_{i j}$ is the covariance of monetary aggregates of country $i$ and $j$ when $i \neq j$. The eigenvalues of the matrix $C M$ show variances of the principal components and can be obtained by solving the characteristic equation. The characteristic equation can be obtained from:

$$
|C M-\lambda I|=0
$$

where, $I$ is the identity matrix of the same order as that of $C M$ and $\lambda$ is the vector of eigenvalues. ${ }^{12}$ 


\section{Currency equivalent (CE) method}

The roots of this method of monetary aggregation can be traced back to the rigorous work of Hutt and Keynes (1963), and Rotemberg et al. (1995). In this method, we first construct the currency equivalent of the broad money of each country and then derive their weighted sum after converting them into a common currency. The aggregation within countries can be sketched as:

$$
c e b m_{i t}=\sum_{j=1}^{J}\left(\frac{R_{i t}-r_{i j t}}{R_{i t}}\right) m_{i j t}
$$

For aggregation across the countries, Chung et al. (2014) use the simple sum method. But, at this stage of aggregation we follow Barnett (2007) where he suggests the aggregation procedure of Divisia index across the countries. We follow him so that the aggregation procedure may be based on theory even at the stage of aggregation across countries. Through the heterogenous-countries approach this procedure can be described as:

$$
\begin{aligned}
& C E_{k t}=\sum_{i=1}^{N} W_{i t}\left(\frac{c e b m_{i t}}{e_{i t}}\right) ; i \in k \\
& \text { where, } W_{i t}=\frac{c e_{i t}^{*} \Pi_{i t} p_{i t}^{*} H_{i t} / e_{i t}}{\sum_{i=1}^{N}\left[c e_{i t}^{*} \Pi_{i t} p_{i t}^{*} H_{i t} / e_{i t}\right]}=\frac{c e_{i t} \Pi_{i t} H_{i t} / e_{i t}}{\sum_{i=1}^{N}\left[c e_{i t} \Pi_{i t} H_{i t} / e_{i t}\right]}
\end{aligned}
$$

and, $c e b m_{i t}$ is the currency equivalent measure of the broad money of country $i$ in time $t, R_{i t}$ is the benchmark rate of return of country $i$ in time $t, r_{i j t}$ is the rate of return of component $j$ in country $i$ at time $t, m_{i j t}$ is the value of component $j$ of the broad money of country $i$ in time $t, C E_{k t}$ is the regional currency equivalent aggregate of region $k$ in time $t, e_{i t}$ is currency exchange rate of country $i$ in time $t, H_{i t}$ is the population of country $i$ in time $t$ and $\Pi_{i t}$ is the user cost price aggregate of country $i$ in time $t$.

The Fisher's factor reversal test claims the existence of a user cost aggregate price dual to the quantity aggregate in a way that their product is equal to the total expenditures on all components. Hence;

$$
\begin{aligned}
\Pi_{i t} M_{i t} & =\sum_{j=1}^{J} \pi_{i j t} m_{i j t} \\
\text { So, } \Pi_{i t} & =\frac{\sum_{j=1}^{J} \pi_{i j t} m_{i j t}}{M_{i t}}
\end{aligned}
$$

where, $\Pi_{i t}$ is the user cost aggregate price for country $i$ at time $t$ and $M_{i t}$ is the quantity aggregate (broad money) of country $i$ at time $t$. We use this method to calculate country specific user cost aggregate price.

We use three to four components of broad money for each country as stated in section 3. So, $J$ ranges from one to four $(J=1,2, \ldots, 4)$ and the currency in circulation or M1 bears no interest. Deposit rate is imputed to transferable deposits included in broad money. The treasury bill rate (hereafter TBR) or money market rate (if TBR is not available) is assigned to other deposits or the constituents of M2 but not of M1. 
Short-term or medium term (if short-term is not available) government bond yield is allocated to deposits other than securities included in broad money or the assets included in M3 but not in M1. However, for the US, we assign TBR to the components incorporated in M1 other than currency in circulation, and short-term bond yield to the components included in M2 but not in M1.

\section{Benchmark rate of return}

The benchmark rate of return $\left(R_{t}\right)$, as defined by Barnett (1987), is the return obtained on an investment asset, purely held for accumulating wealth, and which does not perform any other service such as liquidity. Researchers use different proxies for it. Usually, the investigators follow the envelope approach: the highest rate of interest is used as a proxy (Alkhareif and Barnett 2012; Serletis and Molik 2000). Some other researchers construct its proxy by adding liquidity premia to the selected rate of interest (Stracca 2004). ${ }^{13}$ This study also follows the envelope approach in most of the cases but only in a very few cases we have constructed a benchmark rate of return by adding liquidity premia. ${ }^{14}$ In most of the sampled countries, the highest rate of interest is the lending rate, so, we use that as the benchmark rate of interest.

\section{Divisia index}

The Divisia index meets the standards of the class of superlative index numbers as defined by Diewert (1976). Its footing primarily rests on the seminal works of Diewert $(1976,1978)$ and Barnett $(1978,1980)$. However, Barnett (1980) succeeded in constructing Divisia monetary aggregates consistent with the microeconomic theory. Therefore, the Divisia monetary index is attributed to Barnett (1980). It entertains three functions of money (medium of exchange, store of value and unit of account) and dismisses investment motives, hence measuring other monetary services related to liquidity (Hancock 2005). This method involves the construction of Divisia indices within countries and then aggregation of the indices across the countries.

\section{Aggregation within countries}

Let $m_{i j t}$ be the per capita value of asset type $j$ (component of broad money) in country $i$ at time $t$ and $\mathrm{J}$ be the total number of asset types in country $i$. Also, let the rate of return of asset $j$ in country $i$ at time $t$ be $r_{i j t}$, and the true cost of living in country $i$ at time $t$ be $p_{i t}^{*}$. Then, the discrete-time approximation to continuous-time Divisia monetary index can then be expressed as:

$$
\begin{aligned}
& M_{i t}=\prod_{j=1}^{J}\left(\frac{m_{i j t}}{m_{i j, t-1}}\right)^{w_{i j t}} \cdot M_{i, t-1} \\
& \text { where, } w_{i j t}=\frac{1}{2}\left(s_{i j t}+s_{i j, t-1}\right) \\
& \text { and, } s_{i j t}=\frac{\left(R_{i t}-r_{i j t}\right) m_{i j t}}{\sum_{j=1}^{J}\left(R_{i t}-r_{i j t}\right) m_{i j t}}=\frac{\pi_{i j t} m_{i j t}}{\sum_{j=1}^{J} \pi_{i j t} m_{i j t}}
\end{aligned}
$$

where, $M_{i t}$ is the Divisia monetary index of the broad money of country $i$ in time $t$, $w_{i j t}$ is the weight allotted to component $j$ of the broad money of country $i$ in time $t, s_{i j t}$ is the 
expenditure share of component $j$ of the broad money of country $i$ in time $t, R_{i t}$ is the benchmark rate of return of country $i$ in time $t$ and $\pi_{i j t}$ is the user cost of component $j$ of broad money of country $i$ in time $t$. The user cost is the return given up due to holding a monetary asset instead of holding an asset with higher return (Barnett 1978). In other words, user cost is the opportunity cost of asset and a representation of its price. It can be calculated as:

$$
\pi_{i j t}=\frac{\left(R_{i t}-r_{i j t}\right)}{1+R_{i t}}
$$

The logarithmic transformation of the Divisia index can be expressed as:

$$
\log M_{i t}-\log M_{i, t-1}=\sum_{j=1}^{J} w_{i j t}\left(\log m_{i j t}-\log m_{i j, t-1}\right)
$$

\section{Aggregation across the countries}

We follow the heterogenous countries approach of Barnett (2007) to construct Divisia index across the sampled countries. Let $N$ be the total number of countries in the group. The population of country $i$ at time $t$ is $H_{i t}$. The discrete-time approximation to continuous-time Divisia monetary index, aggregated across the countries, can be expressed as:

$$
\begin{aligned}
& D I V_{k t}=\prod_{i=1}^{N}\left(h_{i t} M_{i t} / e_{i t}\right)^{W_{i t}^{*}} . D I V_{k, t-1} \text { and } i \in k \\
& \text { where, } h_{i t}=\frac{H_{i t}}{\sum_{i=1}^{N} H_{i t}} \\
& \text { and, } W_{i t}=\frac{M_{i t}^{*} \Pi_{i t}^{*} p_{i t}^{*} H_{i t} / e_{i t}}{\sum_{i=1}^{N}\left[M_{i t}^{*} \Pi_{i t}^{*} p_{i t}^{*} H_{i t} / e_{i t}\right]}=\frac{M_{i t} \Pi_{i t}^{*} H_{i t} / e_{i t}}{\sum_{i=1}^{N}\left[M_{i t} \Pi_{i t}^{*} H_{i t} / e_{i t}\right]} \\
& W_{i t}^{*}=\frac{1}{2}\left(W_{i t}+W_{i, t-1}\right)
\end{aligned}
$$

From the above expression it is apparent that $0 \leq W_{i} \leq 1$ for all $i$, and $\sum_{i=1}^{N} W_{i}=1$. Thereby, we may consider $\left\{W_{1}, \ldots \ldots \ldots, W_{N}\right\}$ as a probability distribution in constructing Divisia means across the countries. $D I V_{k t}$ is the Divisia monetary index for region $k$ at time $t$. The remaining notations are the same as those in the previous section of CE measure.

The logarithmic transformation of Divisia indices can be expressed as:

$$
\log D I V_{k t}-\log D I V_{k, t-1}=\sum_{i=1}^{N} W_{i t}\left[\log \left(\frac{h_{i t} M_{i t}}{e_{i t}}\right)-\log \left(\frac{h_{i, t-1} M_{i, t-1}}{e_{i, t-1}}\right)\right]
$$

Through Fisher's factor reversal property of user cost aggregates and monetary quantity the user cost aggregate across the countries can be obtained as: 


$$
\Pi_{t}=\frac{\sum_{i=1}^{N}\left(M_{i t} s_{i t} \Pi_{i t} / e_{i t}\right)}{M_{t}}
$$

\section{Discussion}

This section discusses the dynamics of different measures of monetary aggregation over time. It examines their interrelationships and behaviours, especially during the periods of financial turbulence in different regions and countries. The severe financial catastrophe with widespread impact erupted during the period of investigation of this study is the global financial crisis of 2007-2008. This section proceeds on investigating the dynamics of monetary aggregates at a regional and then a global level.

\section{East Asia and Pacific}

Figure 1 shows that the theory-based measures of monetary aggregates envelop the other atheoretical measures. The $\mathrm{CE}$ and Divisia monetary aggregates undergo substantial variations especially during the period of the global financial crisis (2007-2008) and its aftermath, which indicates prevalent uncertainty during the period. The positive growth rate of around 4\% registered by the Divisia index in the beginning of 2002 indicates the recovery from the Asian financial crisis (1997) during which Japan and Korea were fiercely hit, and Japan took around seven years to recover (Reinhart and Rogoff 2014). After this, till the end of 2005, all the measures show normal behaviour. From late 2005 to the beginning of 2007, the theoretic measures record a negative growth rate most of the times, indicating a gradually squeezed liquidity. Both the measures record huge variations throughout 2007 to 2014 supporting the view of Reinhart and

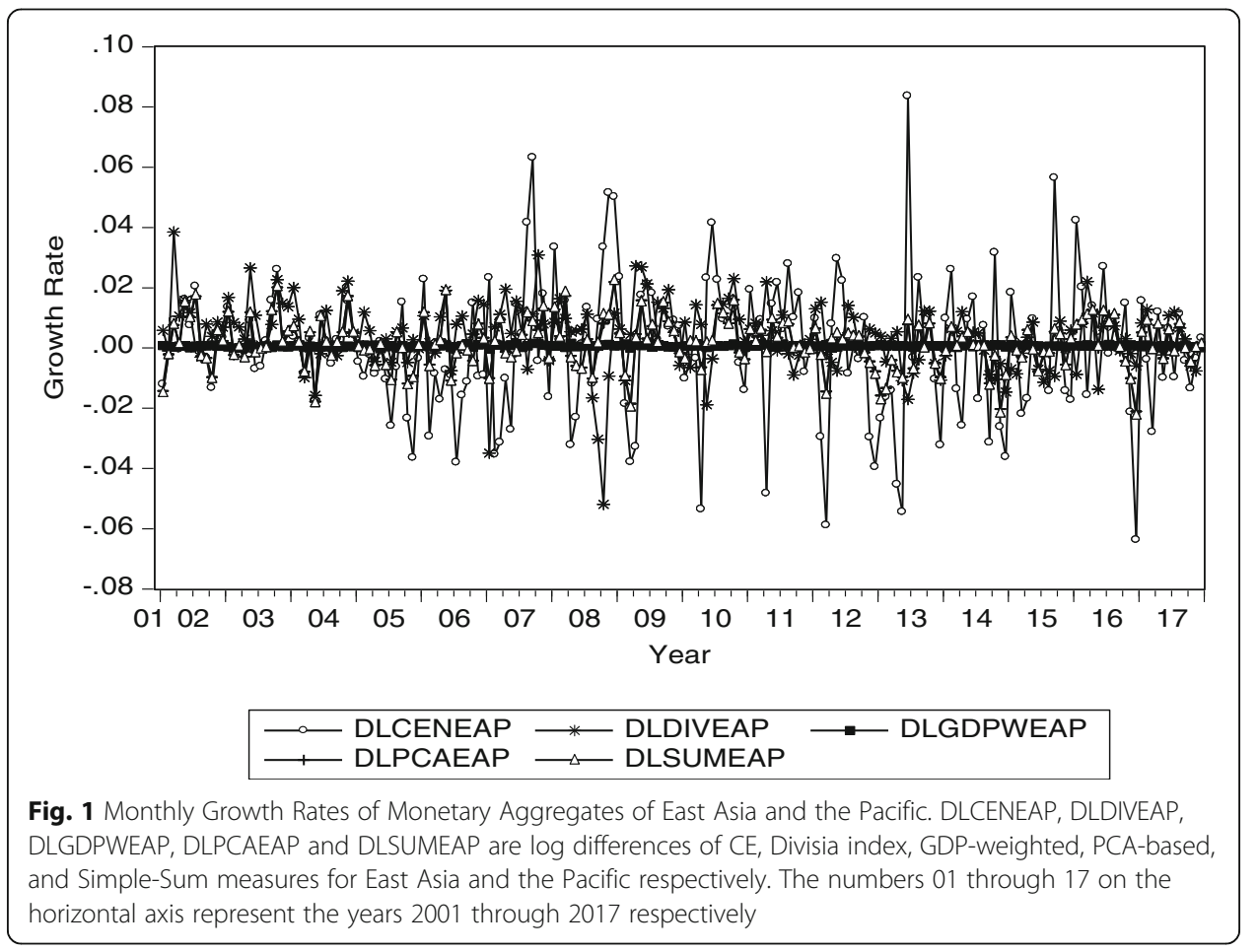


Rogoff (2014). They argue that the impact of the global financial crisis lasted for around seven years. During this period the Divisia and CE aggregates, most of the time, undergo negative growth rate. The Divisia index records the highest negative growth rate of about $6 \%$ at the end of 2008 while CE measure registers negative growth rate of around 6\% in 2010, 2012 and then in 2013. The period spanning from the end of 2013 to 2015 is the period of relative tranquillity. After this the CE measure records variations again. Contrarily, the atheoretical measures fail to indicate changing financial conditions and especially that the GDP-weighted growth rates measure registers very smooth dynamics in all conditions. Hence, theoretic measures perform better than atheoretical ones as indicators of financial conditions.

\section{Europe and Central Asia}

Figure 2 depicts that the theoretic monetary aggregates are more volatile as compared to the atheoretical ones. The CE and Divisia aggregate curves wrap the curves of other aggregates. The fluctuations in CE and Divisia aggregates gradually increase from 2006 but the amplitude of the swings becomes larger from the end of 2007 onward till 2010. Afterwards, the amplitude of fluctuations decreases gradually, though not as that in normal conditions till 2013. Overall, the oscillations in the growth rates of CE and Divisia aggregates portray the period of 2007 to 2013 as a period of distress. This is in line with the reality that many of the European countries were pinched during the global financial crisis. The European economies suffered from a financial panic in 2007 and 2008 severely and could not recover fully till 2013 (Reinhart and Rogoff, 2014). However, the other measures of monetary aggregates fail to represent and distinguish financial and liquidity conditions clearly.

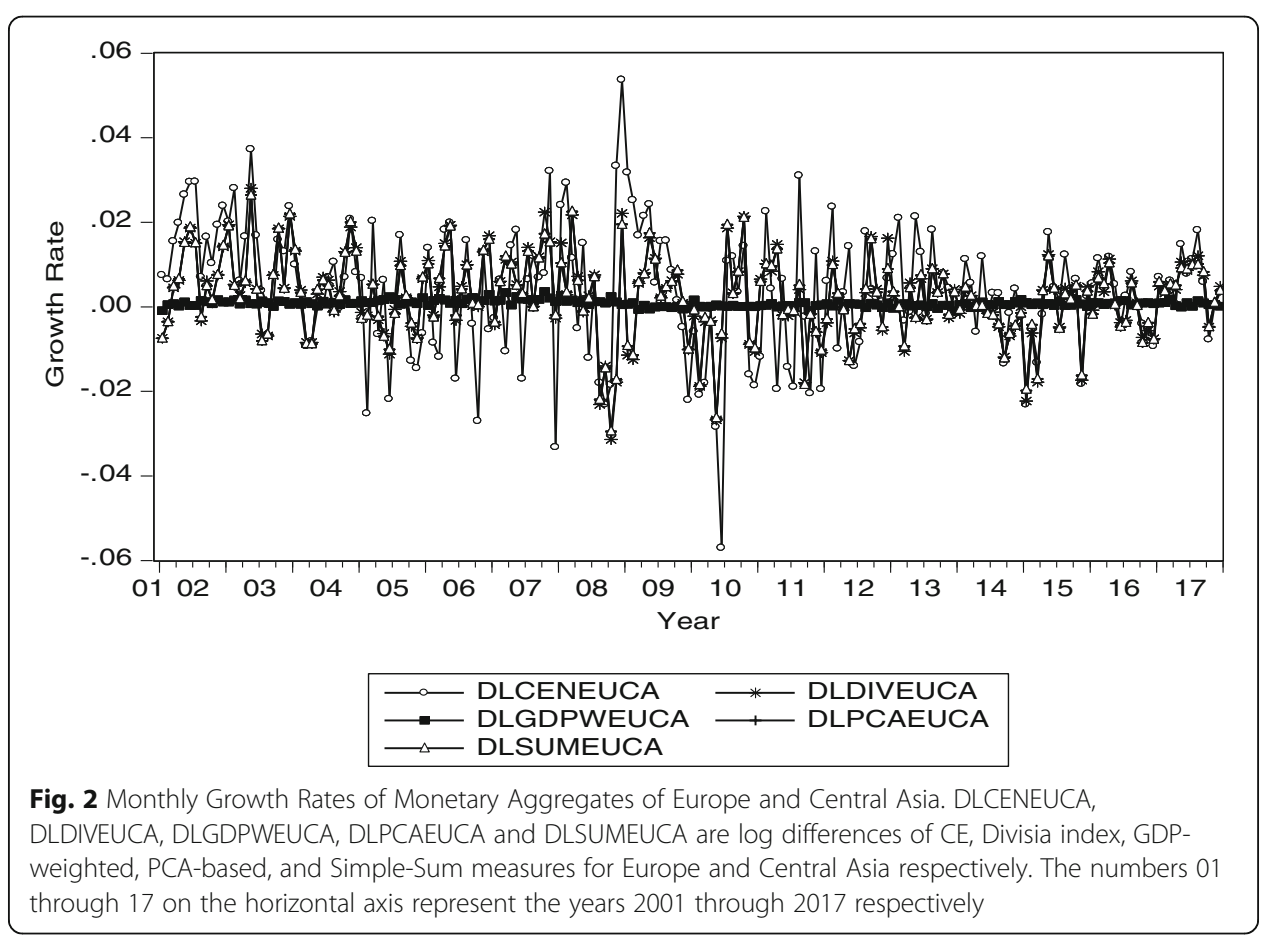




\section{Latin America and Caribbean}

In Fig. 3 a cluster of negative growth rates posted by the Divisia monetary aggregate in 2002 accurately indicates the banking crisis of Uruguay in 2002. The severity index of this crisis, as noted by Reinhart and Rogoff (2014), is 26.9. Later, from 2003 to 2007, a period of tranquillity is portrayed in the figure. During the period of 2007 to 2009 the CE aggregate witnesses two peaks of positive growth rates while the Divisia aggregate undergoes a plunge with negative growth rate of above $25 \%$ in 2008 . The plunge undertaken by the Divisia aggregate corresponds to the financial panic engendered by the global financial crisis. All the measures depict tranquil economic conditions, except for in 2016, where the CE aggregate indicates uncertain financial conditions. The CE measure appropriately captures the uncertain conditions resulting due to slowdown in Uruguay's economy and consequent fiscal and monetary measures taken by the government in 2016. Moreover, the CE and Divisia measures indicate financial and liquidity conditions in a far better way than other measures even in this case.

\section{The Middle East and North Africa}

As mentioned earlier, we have only one country, Israel, in our sample as a representative of this region. In Fig. 4 the CE aggregate presents much variations in 2002-2003 which is the period during which the Israeli government took various steps to strengthen financial stability. As per the Financial Stability Report 2003 prepared by the central bank of Israel, financial conditions in the economy improved because of the fiscal and monetary measures taken by the government. However, the Divisia and other aggregates do not show any kind of financial or liquidity turbulence in the economy during this period. The $\mathrm{CE}$ aggregate again posts fluctuations in the span of 2007 to 2009, while the Divisia aggregate registers very small variations. The Israeli economy was not affected by the global financial crisis to

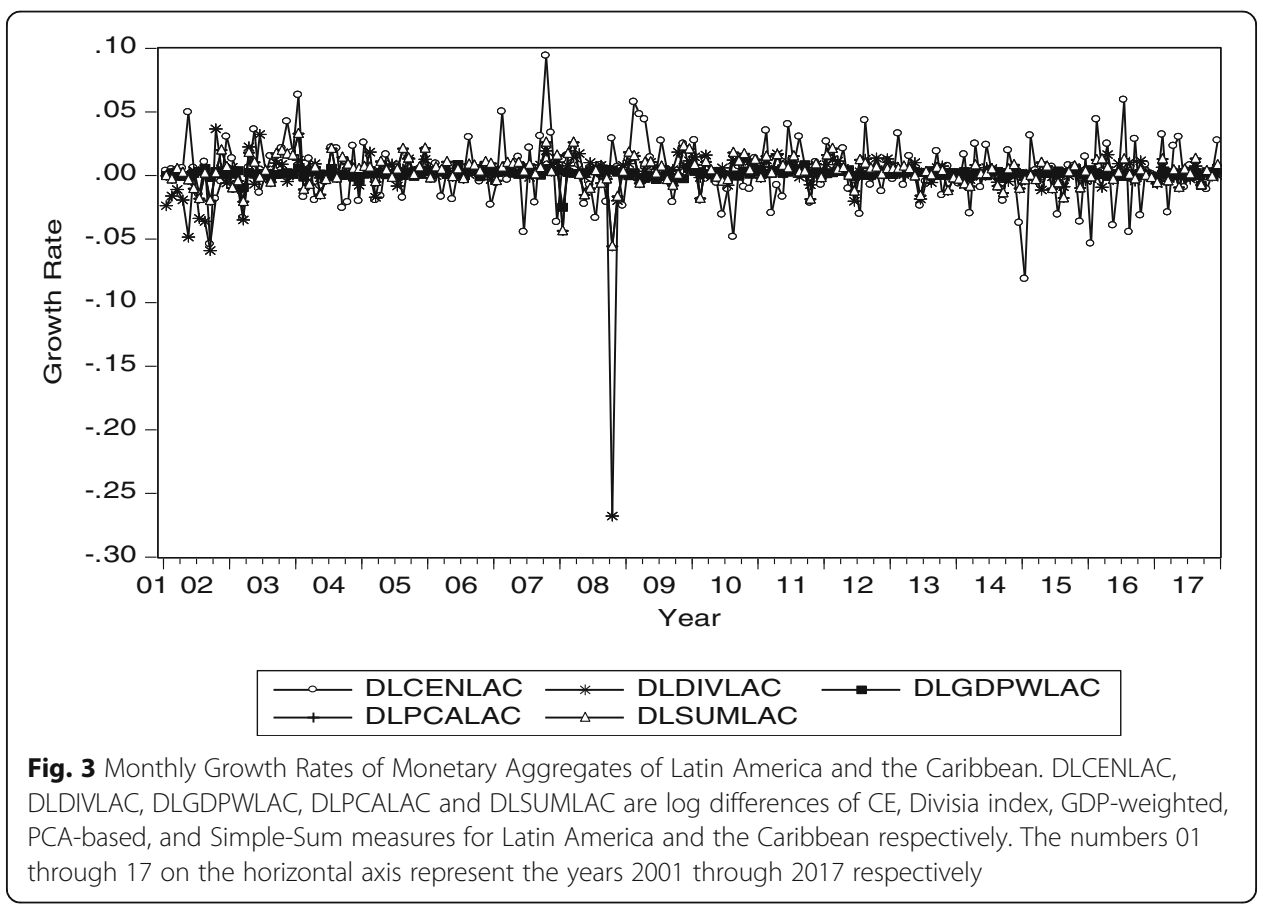




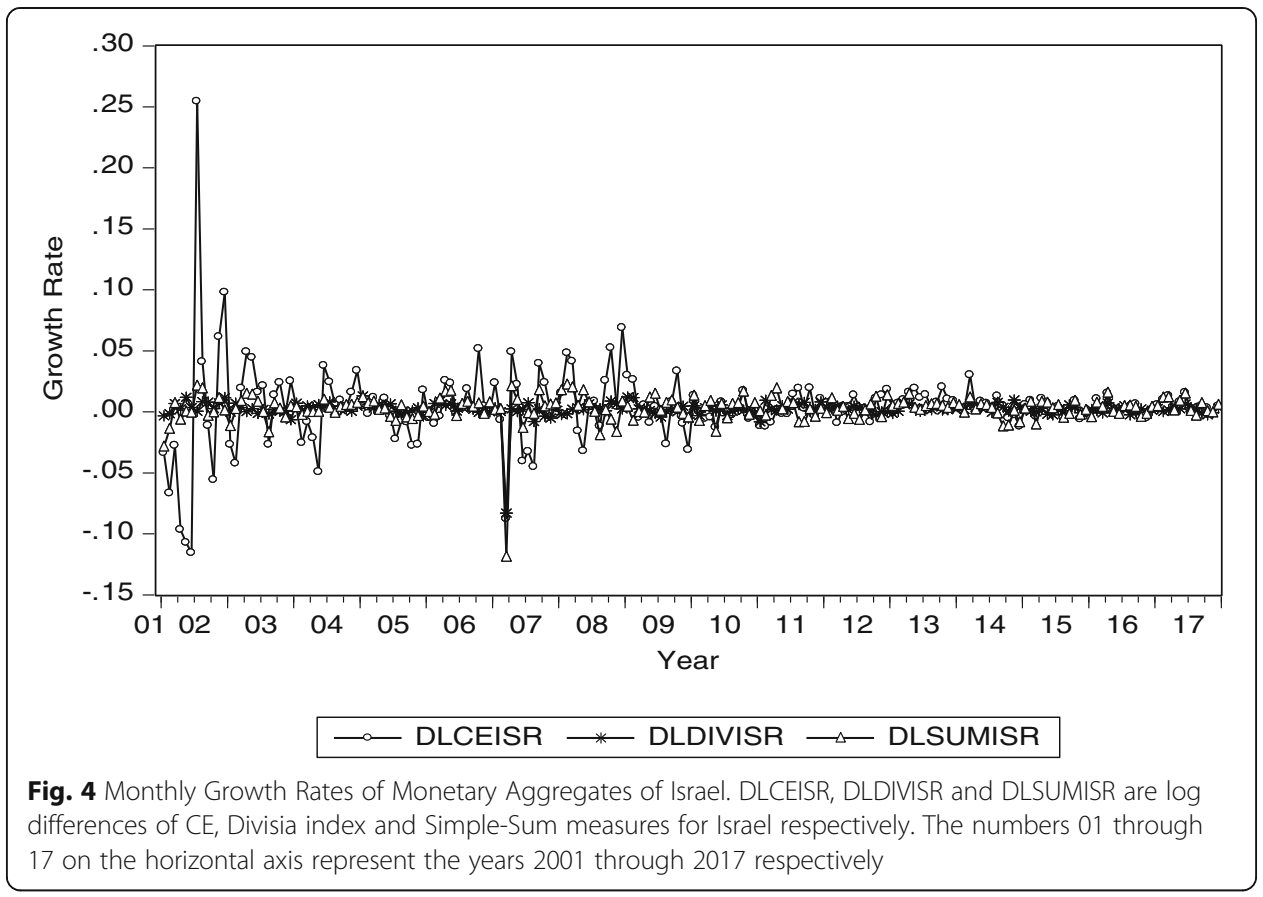

much of an extent as compared to other major economies of the world. Yet, the Israeli authorities undertook some measures to ward off the impact of the global financial crisis. All the aggregates show a smooth trend after 2009.

\section{North America}

In Fig. 5 (a) the CE monetary aggregate records huge variations from the beginning of the sample period to 2004, pointing to the uncertain conditions prevailing in the US due to the 9/11 incident, and the subsequent Afghan and Iraq wars. The economic and financial horizons of the country were overcast with uncertainty resulting in the loss of investor and consumer confidence. However, the other monetary aggregates do not show any panic during this period. This might be due to the fact that the US economy did not witness any severe setback during this period. Nevertheless, the US government undertook some fiscal and monetary steps to pacify the situation and to muster investor and consumer confidence, as reported by the Presidential Economic Reports of 2003 and 2004 of the US. All the monetary aggregates undergo considerable fluctuations in 2007 to 2012, pointing to fragile financial and liquidity conditions of the US economy during the global financial crisis [Figs. 5 (a) and (b)]. The US economy was squeezed by this financial panic in 2007 and recovered from it in 2013 (Reinhart and Rogoff, 2014).

\section{Global scenario}

Figure 6 depicts global financial and liquidity conditions through the lens of monetary aggregates. All the aggregates fluctuate, but the CE aggregate is most variant, and the GDP-weighted growth rates aggregate is least variant throughout the sample period. The CE and Divisia aggregates encompass the other measures. However, the amplitude of variations in the Divisia aggregate is smaller than that of the CE aggregate. The larger variation posted by the CE aggregate in 2002 might be due to the uncertainty 


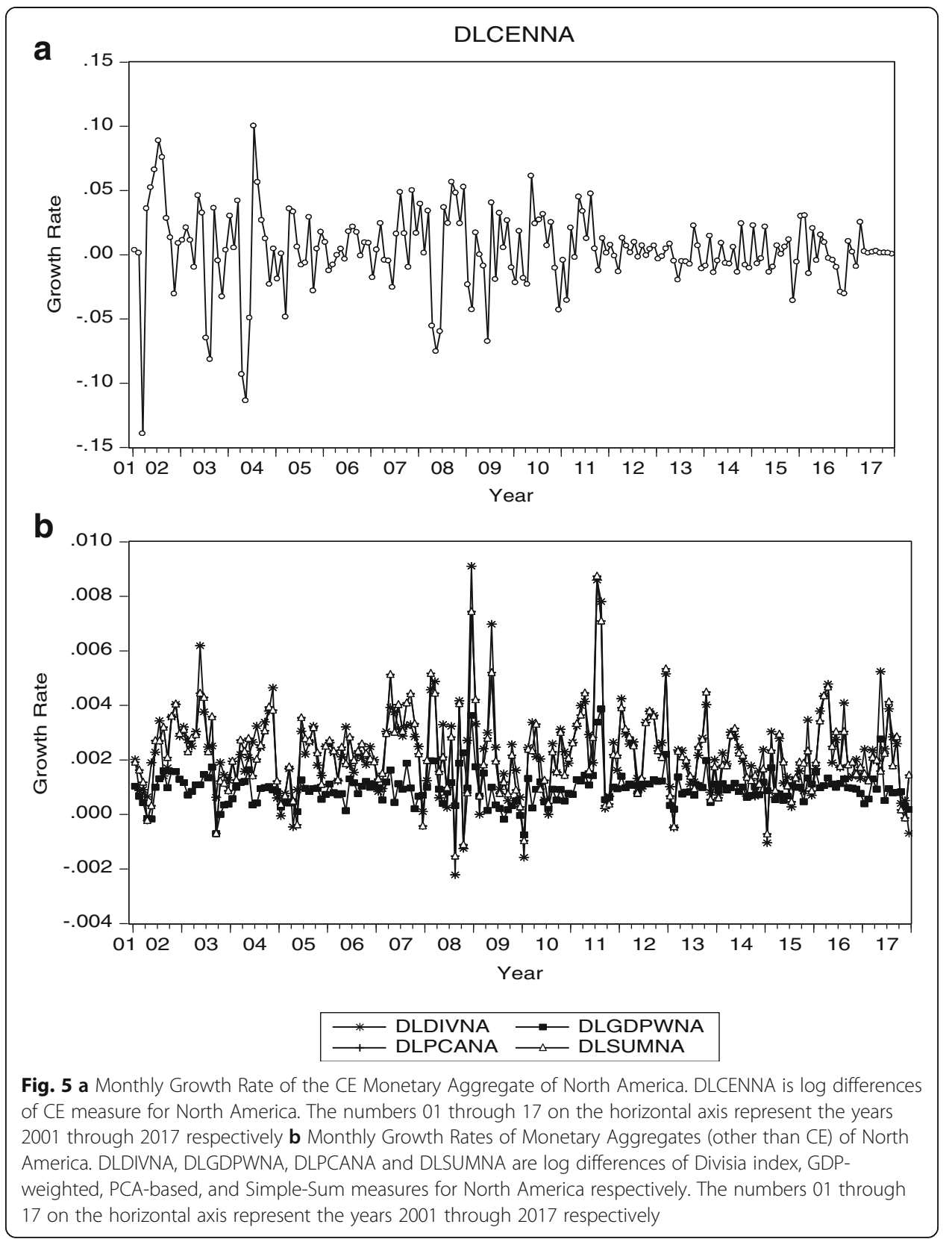

engendered by the $9 / 11$ incident. A cluster of positive growth rates indicates an expansionary period after the Asian financial crisis and Uruguay crisis of 2002. From 2002 to the start of 2007, all the aggregates show normal behaviour with a mixture of positive and negative growth rates. It is from 2007 to the end of the sample period that clusters of positive and negative growth rates start to follow each other frequently. The clusters of positive and negative growth rates might be due to the fact that we use monthly data. During the period of 2007 to 2013, all the aggregates oscillate with a larger amplitude, which can be accorded to the uncertain and fragile financial conditions resulting from the global financial crisis. From 2014 to the end of the sample period, a smaller amplitude of variations represents normalized conditions. 


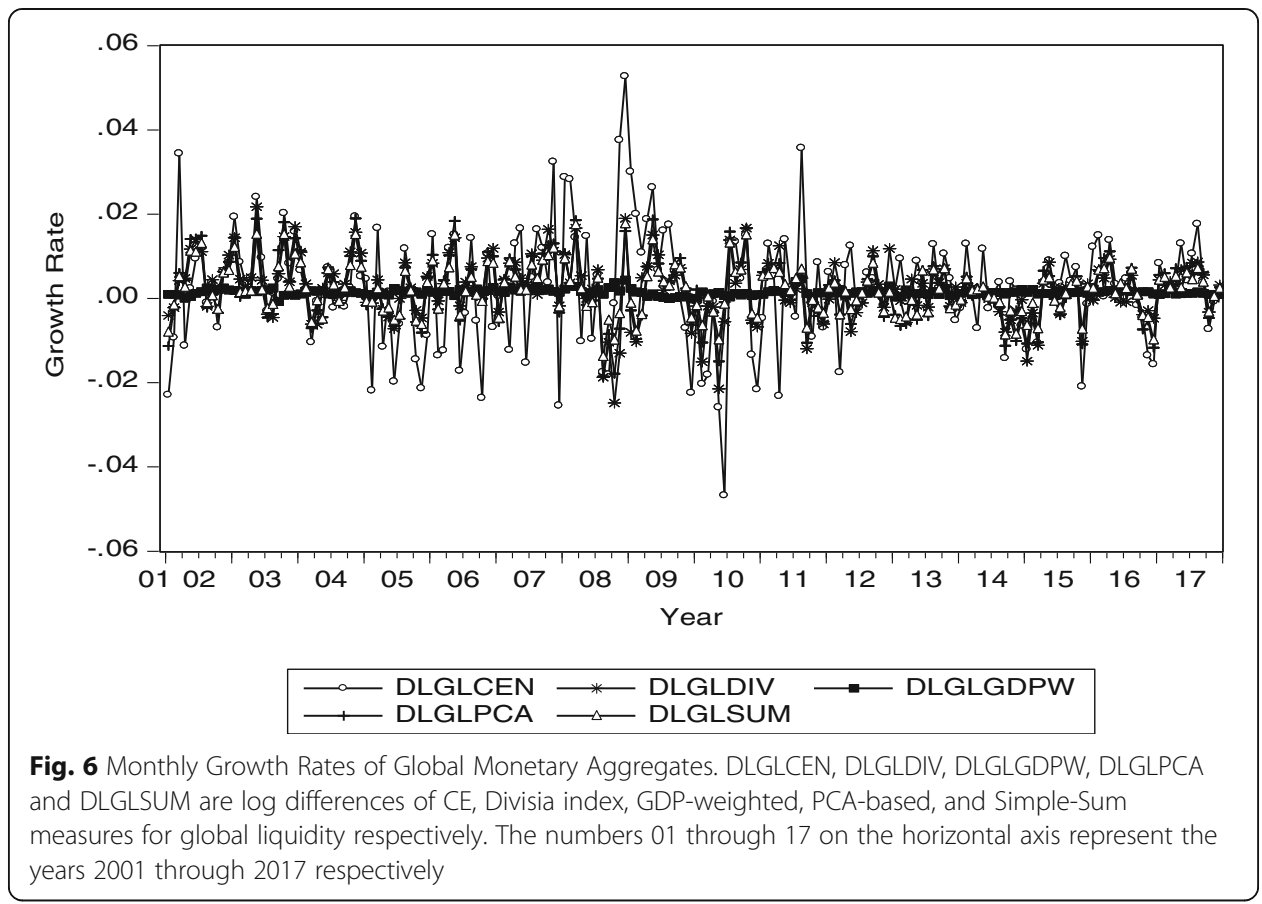

The Divisia user cost of monetary assets accurately delineates the financial conditions and policy stance of each region and on a global scale. This reflects the uncertainty and fragility of financial conditions in almost every economic and financial distress such as the 9/11 incident, the Uruguay banking crisis of 2002 and the global financial crisis of 2007-2008. It subtly distinguishes the periods of tranquillity and turbulence. For this reason, it supports the stance of Alkhareif and Barnett (2012) that the Divisia user cost can act as a good indicator of financial and liquidity conditions. ${ }^{15}$

\section{Cross-correlation analysis}

This study also examines cross-correlation between cyclical components of global real economic activity (hereafter GREA) and up to 48 lags of the cyclical components of the measures of global liquidity in the manner of Belongia and Ireland (2017) (see Table 1 in Appendix). GREA is proxied by the OECD industrial production index. ${ }^{16} \mathrm{We}$ calculate the cyclical components through the latest procedure suggested by Hamilton (2018a) for first order integrated series. ${ }^{17}$ The cross-correlation analysis authenticates the superiority of theoretical measures for having stronger correlation than that of atheoretical ones with GREA. The highest correlation coefficient for the case of CE measure is -0.8471 at its current level (zero lag), -0.7101 at its 16th lag for the Divisia index, -0.589 at its 10 th lag for the GDP-weighted indicator, -0.5593 at its 14 th lag for the simple-sum measure and -0.5865 at its 17 th lag for the PCA-based measure.

We document quite a variety of results; as the correlation between cyclical components of GREA and the current level of the cyclical components of CE and GDP-weighted measures is negative while it, though possibly negligible, is positive for the current level of cyclical components of Divisia, simple-sum and PCA measures. Interestingly, we also 
observe a cyclical trend in the correlation coefficients; they gradually plummet and then start soaring after switching from negative to positive at the 15th lag when the CE measure is exploited. For other measures they first rise and then fall, switching from negative to positive at the 34th lag of the Divisia index, the 24th lag of GDP-weighted, the 30th lag of the simple-sum and the 32nd lag of the PCA measure.

\section{Conclusion and policy recommendation}

Global liquidity, despite being highly focused in empirical literature with regards to the aftermath of the global financial crisis, lacks comprehensive measures and definition, while remaining an elusive concept. The growing literature on the issue suggests an array of different aspects of global liquidity and a variety of their respective measures. However, most of the empirical studies exploit its monetary measures for their investigations and most of explorations in this direction make use of atheoretical measures. Investigations that utilize theoretical measures are very scarce.

This study constructs and examines the dynamics and cross-correlation of cyclical components of GREA with the lags of cyclical components of theoretical as well as atheoretical measures of global liquidity using monthly data spanning from December 2001 to December 2017, for 39 high income countries. We inspect the dynamics of monetary aggregates constructed at regional and global levels. To this end, we group the countries, as classified by the World Bank, into five regional blocks: East Asia and the Pacific, Europe and Central Asia, Latin America and the Caribbean, the Middle East and North Africa, and North America. Our atheoretical measures comprise of the simple-sum, GDP-weighted growth rates and PCA based aggregation methods. Theoretical measures include $\mathrm{CE}$ and Divisia index techniques of monetary aggregation. The $\mathrm{CE}$ technique is a stock measure and the Divisia index is a flow measure.

Therefore, this study constructs and investigates both stock and flow measures of monetary aggregates supported by the microeconomic theory. Firstly, it employs a graphical approach for investigation, so that trends and dynamics of the aggregates can be examined overtime. Secondly, it investigates the strength and nature of correlations between cyclical components of GREA and those of the indicators of global liquidity. The findings of the study reveal that theoretical measures outperform atheoretical ones in effective depiction of the financial and liquidity conditions, and policy stance. Besides, the correlation analysis validates the pre-eminence of theoretical measures for having stronger correlation than that of atheoretical ones with GREA. The CE measure is not only a good indicator of the shift in policy stance but also has the strongest association with GREA. The Divisia index too has a stronger association than all other measures except CE with GREA. Moreover, the theoretical measures, as noted by empirical studies, contain some information content while the atheoretical ones do not. However, all the monetary aggregates are highly correlated, with the correlation coefficient being greater than 0.85 .

Based on our findings, we recommend that central banks of the world should collect and issue data on the components of monetary aggregates and their respective interest rates. They should incorporate theoretical measures, and CE and Divisia monetary aggregates among intermediate targets of monetary policy. Further, they can formulate 
their policy stance keeping in view the information provided by the theoretical measures, so that they can effectively cope with economic and financial problems. Moreover, this study attempts to attract the attention of researchers to utilize theoretical measures of global liquidity to better understand and explore its role in global financial stability, and its nexus with macroeconomic and financial variables. Researchers may also use the suggested measures to investigate the role of global liquidity, particularly in business cycles, to underline the monetary stance that would potentially prevent fluctuations in business activities for future endeavours.

\section{Endnotes}

${ }^{1}$ See Committee on Global Financial System (CGFS) report (2011) for detailed description of the measures of global liquidity.

${ }^{2} \mathrm{CDS}$ is a financial swap agreement which requires the seller of CDS to compensate its buyer in case of loan default or any other undesirable event.

${ }^{3}$ Libor-OIS spread refers to the difference between two interest rates, London Interbank Offered Rate (LIBOR) and the Overnight Indexed Swap (OIS) rate.

${ }^{4} \mathrm{VIX}$ is the ticker symbol for the CBOE Volatility Index and is a measure of the implied volatility of S\&P 500 index options. It is calculated by Chicago Board Options Exchange (CBOE).

${ }^{5}$ MOVE index is the Merrill Lynch Options Volatility Estimate (MOVE) index. It is the weighted (yield curve weighted) index of normalized implied volatility of one-month Treasury options.

${ }^{6}$ The CFS is a think tank focused on financial markets, located in New York, America.

${ }^{7}$ We follow the World Bank list of economies (March 2017) for the classification of countries.

${ }^{8}$ We treat $\mathrm{EU}_{19}$ as a single unit because these countries use euro while other members of the European Union do not use euro as their national currency (the European Commission).

${ }^{9}$ The data on broad money starts from December 2001, as reported in IFS and we exclude the countries with insufficient data on monetary aggregates and interest rates from our sample.

${ }^{10}$ We use M1 because it comprises of currency in circulation and demand deposits which bear almost zero interest for almost all these countries.

${ }^{11}$ The monetary aggregates of the UK and Canada were already seasonally adjusted.

${ }^{12}$ The results of PCA analysis will be provided on demand.

${ }^{13}$ For the detailed discussion on the construction of proxies for benchmark rate of return, please see Barnett (2003).

${ }^{14} \mathrm{We}$ have constructed benchmark rate of return by adding liquidity premia for Denmark, Hungary, Korea Republic, Norway, Poland, Sweden and the UK.

${ }^{15}$ Figures on the monthly growth rate of the Divisia user cost of monetary assets, at regional and global levels, can be requested from authors.

${ }^{16}$ Since OECD industrial production index is widely used as a proxy of global real economic activity in monthly data analysis (Hamilton, 1988b; Ciccarelli and Mojon, 2010), Hamilton (2018b) favours the use of this index as an indicator of global economic activity.

${ }^{17}$ Because the series under inspection are integrated of order one. 


\section{Appendix}

Table 1 Correlation between Cyclical Components of GREA and Lags of the Cyclical Components of Various Measures of Global Liquidity

\begin{tabular}{|c|c|c|c|c|c|}
\hline & GLCEN & GLDIV & GLGDPW & GLSUM & GLPCA \\
\hline LO & -0.8471 & 0.0926 & -0.2556 & 0.0016 & 0.0649 \\
\hline L1. & -0.8228 & 0.0574 & -0.3262 & -0.0184 & 0.0488 \\
\hline L2. & -0.7872 & 0.012 & -0.3857 & -0.0455 & 0.0232 \\
\hline L3. & -0.7423 & -0.0452 & -0.4354 & -0.0801 & -0.0123 \\
\hline L4. & -0.6986 & -0.1209 & -0.4765 & -0.131 & -0.0654 \\
\hline L5. & -0.6582 & -0.2058 & -0.5124 & -0.193 & -0.1298 \\
\hline L6. & -0.6137 & -0.2912 & -0.5412 & -0.2587 & -0.1992 \\
\hline L7. & -0.5599 & -0.3711 & -0.5638 & -0.3224 & -0.2666 \\
\hline L8. & -0.5002 & -0.4435 & -0.5787 & -0.38 & -0.3297 \\
\hline L9. & -0.4363 & -0.5081 & -0.587 & -0.4317 & -0.3882 \\
\hline L10. & -0.3697 & -0.5672 & -0.589 & -0.4785 & -0.4421 \\
\hline L11. & -0.2986 & -0.6141 & -0.5758 & -0.5127 & -0.4864 \\
\hline L12. & -0.2238 & -0.6502 & -0.5587 & -0.5373 & -0.5217 \\
\hline L13. & -0.1427 & -0.6782 & -0.5348 & -0.5528 & -0.5498 \\
\hline L14. & -0.0594 & -0.6964 & -0.5057 & -0.5593 & -0.5696 \\
\hline L15. & 0.0222 & -0.7055 & -0.4702 & -0.5555 & -0.5794 \\
\hline L16. & 0.098 & -0.7101 & -0.4281 & -0.5483 & -0.5854 \\
\hline L17. & 0.1672 & -0.7092 & -0.3797 & -0.5352 & -0.5865 \\
\hline L18. & 0.2299 & -0.7007 & -0.3245 & -0.5134 & -0.5791 \\
\hline L19. & 0.2884 & -0.6865 & -0.2671 & -0.4846 & -0.5644 \\
\hline L20. & 0.3382 & -0.6678 & -0.2071 & -0.4555 & -0.5485 \\
\hline L21. & 0.3782 & -0.6486 & -0.1488 & -0.4252 & -0.5311 \\
\hline L22. & 0.412 & -0.626 & -0.0891 & -0.39 & -0.5086 \\
\hline L23. & 0.4362 & -0.5958 & -0.0298 & -0.3489 & -0.4792 \\
\hline L24. & 0.4529 & -0.5604 & 0.0254 & -0.3045 & -0.4447 \\
\hline L25. & 0.4629 & -0.5198 & 0.0751 & -0.2595 & -0.4072 \\
\hline L26. & 0.4684 & -0.4732 & 0.1193 & -0.2118 & -0.3646 \\
\hline L27. & 0.4691 & -0.4181 & 0.1592 & -0.1587 & -0.3142 \\
\hline L28. & 0.4678 & -0.3519 & 0.1897 & -0.0977 & -0.2533 \\
\hline L29. & 0.4674 & -0.2826 & 0.2189 & -0.0317 & -0.1871 \\
\hline L30. & 0.464 & -0.2161 & 0.2477 & 0.0321 & -0.1216 \\
\hline L31. & 0.4571 & -0.1512 & 0.2717 & 0.0946 & -0.057 \\
\hline L32. & 0.446 & -0.0886 & 0.2915 & 0.1528 & 0.0056 \\
\hline L33. & 0.4353 & -0.0237 & 0.309 & 0.2138 & 0.071 \\
\hline L34. & 0.4234 & 0.0419 & 0.3221 & 0.276 & 0.1377 \\
\hline L35. & 0.4082 & 0.1012 & 0.3285 & 0.3287 & 0.1969 \\
\hline L36. & 0.3901 & 0.1551 & 0.3369 & 0.379 & 0.253 \\
\hline L37. & 0.3689 & 0.2003 & 0.3454 & 0.4252 & 0.3035 \\
\hline L38. & 0.3394 & 0.2292 & 0.3533 & 0.4546 & 0.3383 \\
\hline L39. & 0.3076 & 0.2471 & 0.3616 & 0.4668 & 0.357 \\
\hline L40. & 0.2753 & 0.256 & 0.3678 & 0.4678 & 0.3649 \\
\hline L41. & 0.2409 & 0.2542 & 0.3731 & 0.4504 & 0.3569 \\
\hline
\end{tabular}


Table 1 Correlation between Cyclical Components of GREA and Lags of the Cyclical Components of Various Measures of Global Liquidity (Continued)

\begin{tabular}{llllll}
\hline & GLCEN & GLDIV & GLGDPW & GLSUM & GLPCA \\
\hline L42. & 0.2081 & 0.2439 & 0.3771 & 0.4231 & 0.3388 \\
L43. & 0.1755 & 0.2292 & 0.3796 & 0.3884 & 0.3134 \\
L44. & 0.1403 & 0.2049 & 0.3787 & 0.3473 & 0.2808 \\
L45. & 0.1051 & 0.1752 & 0.3759 & 0.301 & 0.2433 \\
L46. & 0.0721 & 0.1454 & 0.3708 & 0.2536 & 0.2046 \\
L47. & 0.0433 & 0.1128 & 0.362 & 0.2059 & 0.1643 \\
L48. & 0.0162 & 0.0729 & 0.3526 & 0.1531 & 0.1178 \\
\hline
\end{tabular}

Note: GREA is global real economic activity. GLCEN is a currency-equivalent, GLDIV is a Divisia, GLGDPW is a GDPweighted, GLSUM is a simple-sum and GLPCA is a PCA-based measure of global liquidity. L0 through L48 are lags of global liquidity measures

\begin{abstract}
Abbreviations
CANSIM: Canadian Socio-Economic Information Management System; CE: Currency Equivalent; CFS: Centre for Financial Stability; CFTC: Commodity Futures Trading Commission; CGFS: Committee on Global Financial System; CP: Commercial Paper; CSD: Credit Default Swap; DLCEISR: Log difference of currency equivalent measure for Israel; DLCENEAP: Log difference of currency equivalent measure for East Asia and Pacific; DLCENEUCA: Log difference of currency equivalent measure for Europe and Central Asia; DLCENLAC: Log difference of currency equivalent measure for Latin America and Caribbean; DLCENNA: Log difference of currency equivalent measure for North America; DLDIVEAP: Log difference of Divisia index for East Asia and Pacific; DLDIVEUCA: Log difference of currency Divisia index for Europe and Central Asia; DLDIVISR: Log difference of Divisia index for Israel; DLDIVLAC: Log difference of Divisia index for Latin America and Caribbean; DLDIVNA: Log difference of Divisia index for North America; DLGDPWEAP: Log difference of GDP-weighted measure for East Asia and Pacific; DLGDPWEUCA: Log difference of GDP-weighted measure for Europe and Central Asia; DLGDPWLAC: Log difference of GDP-weighted measure for Latin America and Caribbean; DLGDPWNA: Log difference of GDP-weighted measure for North America; DLGLCEN: Log difference of currency equivalent measure of global liquidity; DLGLDIV: Log difference of Divisia index of global liquidity; DLGLGDPW: Log difference of GDP-weighted measure of global liquidity; DLGLPCA: Log difference of PCAbased measure of global liquidity; DLGLSUM: Log difference of simple-sum measure of global liquidity; DLPCAEAP: Log difference of PCA-based measure for East Asia and Pacific; DLPCAEUCA: Log difference of PCA-based measure for Europe and Central Asia; DLPCALAC: Log difference of PCA-based measure for Latin America and Caribbean;

DLPCANA: Log difference of PCA-based for North America; DLSUMEAP: Log difference of simple-sum measure for East Asia and Pacific; DLSUMEUCA: Log difference of currency equivalent measure for Europe and Central Asia; DLSUMISR: Log difference of simple-sum measure for Israel; DLSUMLAC: Log difference of simple-sum measure for Latin America and Caribbean; DLSUMNA: Log difference of simple-sum for North America; EU: Euro Area; FRED: Federal Reserve Economic Data; GDP: Gross Domestic Product; GFC: Global Financial Crisis; GLCEN: Currency-equivalent measure of global liquidity; GLDIV: Divisia index of global liquidity; GLGDPW: GDP-weighted growth rates measure of global liquidity; GLPCA: PCA based measure of global liquidity; GLSUM: Simple-sum measure of global liquidity; GREA: Global real economic activity; IFS: International Financial Statistics; IMF: International Monetary Fund; LiborOIS: London Interbank Offer Rate and Overnight Indexed Swap; MOVE: Merrill Lynch Options Volatility Estimate; PCA: Principal Component Analysis; TBR: Treasury Bill Rate; UK: The United Kingdoms; US: The United States; VIX: Volatility Index of Chicago Board Options Exchange
\end{abstract}

\title{
Acknowledgements
}

The authors would like to thank the respected reviewers for their valuable comments

\section{Funding}

Not applicable

\section{Availability of data and materials}

The data used in this study is obtained from IMF: http://data.imf.org/?sk=388DFA60-1D26-4ADE-B505-A05A558D9A42; Federal Reserve Economic Data: https://fred.stlouisfed.org/tags/series?t=monetary+aggregates\%3Bunited+kingdom, https://fred.stlouisfed.org/tags/series/?t=monetary+aggregates; OECD database: https://data.oecd.org/industry/ industrial-production.htm; Statistics Canada: Table 10-10-0116-01 Chartered bank assets and liabilities and monetary aggregates, monthly average, seasonally adjusted, Bank of Canada (×1,000,000); URL: https://www150.statcan.gc.ca/t1/ tbl1/en/tv.action?pid=1010011601

\section{Authors' contributions}

IASH and AAB substantially contributed to conception and refinement of the idea, acquisition of data, analysis, and interpretation of data. No one, other than the authors listed above, has substantially contributed towards the manuscript. The authors jointly approve the final manuscript.

\section{Competing interests}

The authors declare that they have no competing interests. 


\section{Publisher's Note}

Springer Nature remains neutral with regard to jurisdictional claims in published maps and institutional affiliations.

\section{Received: 11 January 2019 Accepted: 10 April 2019}

Published online: 24 April 2019

\section{References}

Alkhareif RM, Barnett WA (2012) Divisia monetary aggregates for the GCC countries. In: Barnett WA and Jawadi F (Ed) Recent developments in alternative finance: empirical assessments and economic implications. West Yorkshire, Emerald Press, pp $1-37$

Baks K, Kramer CF (1999) Global liquidity and asset prices: measurement, implications, and spillovers. IMFWorking Paper 99/ 168, Washington, DC

Barnett WA (1978) The user cost of money. Econ Lett 1(2):145-149

Barnett WA (1980) Economic monetary aggregates an application of index number and aggregation theory. J Econ 14(1):11-48 Barnett WA (1984) Recent monetary policy and the Divisia monetary aggregates. Am Stat 38(3):165-172

Barnett WA (1987) The microeconomic theory of monetary aggregation. In: Barnett WA, Singleton, K (Eds.), New approaches to monetary economics, Cambridge University Press, New York

Barnett WA (2003) Aggregation-theoretic monetary aggregation over the euro area, when countries are heterogeneous. European Central Bank Working Paper 260, Frankfurt

Barnett WA (2007) Multilateral aggregation-theoretic monetary aggregation over heterogeneous countries. J Econ 136(2):457-482 Barnett WA, Gaekwad NB (2018) The demand for money for EMU: a flexible functional form approach. Open Econ Rev 29(2):353-371 Barnett WA, Offenbacher EK, Spindt PA (1984) The new Divisia monetary aggregates. J Polit Econ 92(6):1049-1085 Barnett WA, Su L (2017) Data sources for the credit-card augmented Divisia monetary aggregates. Res Int Bus Financ 39:899-910 Beckmann J, Belke A, Czudaj R (2014) Does global liquidity drive commodity prices? J Bank Financ 48:224-234

Belke A, Bordon IG, Volz U (2013) Effects of global liquidity on commodity and food prices. World Dev 44:31-43 Belke A, Keil J (2016) Financial integration, global liquidity and global macroeconomic linkages. J Econ Stud 43(1):16-26 Belke A, Orth W, Setzer R (2010) Liquidity and the dynamic pattern of asset price adjustment: a global view. J Bank Financ 34(8):1933-1945

Belke AH, Bordon IG, Hendricks TW (2014) Monetary policy, global liquidity and commodity price dynamics. N Am J Econ Financ 28:1-16

Belongia MT, Ireland PN (2017) Circumventing the zero lower bound with monetary policy rules based on money. J Macroecon 54:42-58

Beyer A, Doornik JA, Hendry DF (2001) Constructing historical euro-zone data. Econ J 111(469):102-121

Binner JM, Bissoondeeal RK, Elger CT, Jones BE, Mullineux AW (2009) Admissible monetary aggregates for the euro area. J Int Money Financ 28(1):99-114

Borio C, Drehmann M (2009) Assessing the risk of banking crises-revisited. BIS Q Rev:29-46

Brana S, Djigbenou ML, Prat S (2012) Global excess liquidity and asset prices in emerging countries: a PVAR approach. Emerg Mark Rev 13(3):256-267

Bruno V, Shin HS (2014) Cross-border banking and global liquidity. Rev Econ Stud 82(2):535-564

Cerutti E, Claessens S, Ratnovski L (2017) Global liquidity and cross-border bank flows. Econ Policy 32(89):81-125

Chen SF, Liu P, Maechler AM, Marsh C, Saksonovs S, Shin HS (2012) Exploring the dynamics of global liquidity. IMF Working Papers 12/246, Washington, DC

Chung K, Lee JE, Loukoianova E, Park MH, Shin MHS (2014) Global liquidity through the lens of monetary aggregates. IMF Working Papers 14/19, Washington, DC

Ciccarelli M, Mojon B (2010) Global inflation. Rev Econ Stat 92(3):524-535

Cohen BH, Domanski D, Fender I, Shin HS (2017) Global liquidity: a selective review. Annu Rev Econ 9:587-612

Committee on the Global Financial System (CGFS) (2011) Global liquidity_concept, measurement and policy implications. CGFS papers, No. 45

Darius M R (2010) Can global liquidity forecast asset prices? IMF Working Papers 10/196, Washington, DC

Darvas Z (2015) Does money matter in the euro area? Evidence from a new Divisia index. Econ Lett 133:123-126

Diewert WE (1976) Exact and superlative index numbers. J Econ 4(2):115-145

Diewert WE (1978) Superlative index numbers and consistency in aggregation. Econometrica 46(4):883-900.

Domanski D, Fender I, McGuire P (2011) Assessing global liquidity. BIS Q Rev:57-71

Drake L, Chrystal KA, Binner JM (2000) Weighted monetary aggregates for the UK. In: Divisia monetary aggregates. Palgrave Macmillan, London, pp 47-78

Eickmeier S, Gambacorta L, Hofmann B (2014) Understanding global liquidity. Eur Econ Rev 68:1-18

Giese JV, Tuxen CK (2007) Global liquidity and asset prices in a cointegrated VAR. University of Oxford, and Department of Economics, Copenhagen University, Nuffield College, pp 1-28

Hamilton JD (2018a) Why you should never use the Hodrick-Prescott filter. Rev Econ Stat 100(5):831-843

Hamilton JD (2018b) Measuring global economic activity. Manuscript, University of California, San Diego

Hancock M (2005) Divisia money. Bank of England. Q Bull 45(1):39

Hjertstrand P, Swofford JL, Whitney GA (2018) Index numbers and revealed preference rankings. Macroecon Dyn:1-19. https://doi.org/10.1017/\$1365100518000597

Hutt WH, Keynes JM (1963) Keynesianism-retrospect and Prospect. A Critical Restatement of Basic Economic Principles, Chicago

Joint Research Centre-European Commission (2008) Handbook on constructing composite indicators: methodology and user guide. OECD publishing

Landau J (2011) Global liquidity-concept, measurement and policy implications. CGFS Papers 45, Bank for International Settlements, Basel

McGuire P, Sushko V (2015) The BIS global liquidity indicators. IFC Bulletins 39, Bank for International Settlements, Basel

Reinhart CM, Rogoff KS (2014) Recovery from financial crises: evidence from 100 episodes. Am Econ Rev 104(5):50-55 
Rotemberg JJ, Driscoll JC, Poterba JM (1995) Money, output, and prices: evidence from a new monetary aggregate. J Bus Econ Stat 13(1):67-83

Rüffer R and Stracca L (2006) What is global excess liquidity, and does it matter? European Central Bank Working Paper 696, Frankfurt

Schunk DL (2001) The relative forecasting performance of the Divisia and simple sum monetary aggregates. J Money Credit Bank 33(2):272-283

Serletis A, Molik TE (2000) Monetary aggregates and monetary policy. In: Money, monetary policy, and transmission mechanisms, Bank of Canada, Ontario pp. 161-169

Sousa J, Zaghini A (2008) Monetary policy shocks in the euro area and global liquidity spillovers. Int J Financ Econ 13(3):205-218

Stracca L (2004) Does liquidity matter? Properties of a Divisia monetary aggregate in the euro area. Oxf Bull Econ Stat 66(3):309-331

Thornton D, Yue P (1992) An extended series of Divisia monetary aggregates. Fed Reserve Bank St Louis Rev 74 $35-52$

Submit your manuscript to a SpringerOpen ${ }^{\circ}$ journal and benefit from:

- Convenient online submission

- Rigorous peer review

- Open access: articles freely available online

High visibility within the field

- Retaining the copyright to your article

Submit your next manuscript at $\boldsymbol{\nabla}$ springeropen.com 